\section{Behind the Nylon Curtain}

Everyone is now familiar with the Iron Curtain which separates the eastern part of Europe from the west. It is a curtain with many gaps and its solidity is a quality which has bcen conferred upon it by those living outside rather than by any unified effort within. Every country has its ' curtain' today and a ready wit has surrounded the United States with one of nylon. We must be careful that we do not make the Nylon Curtain opaque, for it will be our own fault if we do. These curtains are woven from the strife of monetary difficulties and political creeds, and nothing counteracts them so effectively as a free exchange of men and ideas. One of our contributors is at present in Boston, Massachusetts, and we print below some of his impressions of that centre of medical learning and research which is today a Mecca for so many of our profession.

' I am having a very pleasant time out here, both socially and medically. I find they have the business of entertaining foreign visitors very well organized, and in fact Harvard seems to be a sort of medical Mecca to which new arrivals come throughout the year from all over the world. There is an atmosphere of violent progress and things are going on at an alarming pace, which makes research in England seem almost dilettante in comparison. Nevertheless, some of the flashes of inspiration at home seem to me to be more vivid and illuminating. The mantle of the Teutons has undoubtedly fallen on American shoulders, but a great deal of the work being done gives me the impression of routine investigation. Yet big achievements are undoubtedly being made ; almost every day I make a note of something new and promising, and I hope to add still more when I start my tour of some of the other important centres next month.'

\section{Rheumatoid Arthritis}

Dr. Philip S. Hench, of the Mayo Clinic, will give the Samuel Hyde lecture before the section of physical medicine of the society on Wednesday, October $\mathrm{I}_{3}$, at 4.30 p.m. The title of his lecture is 'A Critical Evaluation of Current Remedies for Rheumatoid Arthritis.' The officers of the section invite those who are not fellows of the society, but who wish to attend, to apply for tickets to Dr. Doris Baker, the Hon. Secretary of the section, at I Wimpole Street, London, W.I.

Once more we have to record a change in the Editorship of our journals. Mr. Selwyn Taylor, M.Ch.(Oxon.), F.R.C.S., who had already received the recognition of his Alma Mater as among those elect to whom the profession looks for research in the science and practice of surgery, has recently been awarded a Rockefeller Travelling Fellowship, and will be leaving this country shortly to begin his studies in the United States. We offer him our warmest congratulations and wish him the best of good fortune and success in his work.

To his successor in the Editorial chair, Mr. A. K. Monro, M.D.(Cantab.), F.R.C.S.(Eng.), we extend the hand of welcome. Mr. Monro is in touch both with the academic and with the practical aspects of medicine and surgery, and we are glad to be able to place the literary fortunes of the Journals into the hands of one who is so well qualified to uphold their reputation and to maintain the high standards at which we have always done onr best to aim.

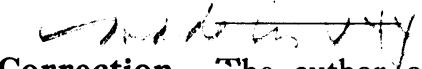

Correction. The author of 'Herniation of Bladder, Simulating a Direct Inguinal Hernia,' published in the September issue of the Journal is David Cromie, F.R.C.S.(Ed.). 